\title{
СООТНОШЕНИЕ ПРАВА И МОРАЛИ В СОВРЕМЕННОЙ ФИЛОСОФИИ ПРАВА
}

\author{
Ю. В. Сорокина \\ Воронежский государственный университет \\ Поступила в редакцию 15 июля 2020 г.
}

\begin{abstract}
Аннотация: исследуются истоки возникновения морали, в тол числе психологическая составляющая. Анализируются дискуссии между представителяли позитивизла и сторонниками других доктрин правопонилания, в частности привержениали школь утилитаристов, естественно-правовой теории. Особо исследован вопрос, связанный с колмуникативной теорией права, которая предлагает расслатривать соиионорлативные систель с культурально-партикулярной точки зрения. Расслатривается спор о присутствии универсалий в праве и морали.

Ключевые слова: психология, позитивизл, лораль, нравственность, право, колмуникация, суд, универсалии, культура, фбилософбия.
\end{abstract}

\begin{abstract}
: this article is devoted to the problems of correlation of law and morality. The origins of the emergence of morality, including the psychological component, are investigated. It also analyzes the discussions between representatives of positivism and supporters of other doctrines of legal understanding, in particular, adherents of the school of utilitarians, natural-law theory. Particularly investigated is the issue related to the communicative theory of law, which proposes to consider socionormative systems from a culturally particular point of view. The debate on the presence of universals in law and morality is being examined. Key words: psychology, positivism, morality, morality, law, communication, court, universals, culture, philosophy.
\end{abstract}

Вопрос о соотношении морали и права - один из главных вопросов теории и философии права. Очевидно, что право и мораль взаимосвязаны между собой в том смысле, что эти нормативные системы воздействуют на общественные отношения и являются особыми способами социальной коммуникации. Приступая к исследованию проблемы, прежде всего рассмотрим понятие и истоки морали.

C. С. Арнольди в замечательном труде «Современные учения о нравственности и ея история», изданном в Санкт-Петербурге в 1904 г., обращает внимание на то, что невозможно найти точного обозначения понятий морали и нравственности, поскольку истоки и первоначальный смысл их заложены в психологии человека. Он пишет: «То чувство, которое испытывает каждый, когда его мысль уясняется, знания расширяются, - есть особенное состояние духа, для которого с точки зрения субъективной едва ли можно найти выражение более близкое, нежели выражение - возвышенное существо» ${ }^{1}$.

${ }^{1}$ Арнольди С. С. Современные учения о нравственности и ея история. СПб., 1904. C. 26.

(c) Сорокина Ю. В., 2020 


\section{Вестник ВГУ. Серия: Право}

Человек, по его мнению, способен испытывать наслаждение от чувства, что он является высоконравственным человеком. По современным меркам это звучит несколько наивно и может даже высокопарно. Но доля истины в данном высказывании, безусловно, имеется: многие люди прямо говорят о чувстве удовлетворения от внутреннего состояния, когда они ощущают себя этически сформированными, культурными и нравственными людьми. В данном случае С. С. Арнольди имеет в виду европейские стандарты морали и культуры, поскольку из его текста ясно, что нравственность рассматривается им как общественная мораль, принятая в западном обществе. Рассуждая о чувстве удовлетворения, которое способно породить самоощущение моральности, надо иметь в виду, что мораль имеет двоякую природу. С одной стороны, ее истоки заложены в природе человека, в его психологическом устройстве, а с другой - мораль имеет принудительный характер, обязывая к определенному типу поведения и даже к определенному образу мыслей. Общество, начиная с семьи, как правило, постепенно и имплицитно формирует у человека моральные устои, которые им часто прямо не осознаются и превращаются в привычку. В конце концов они буквально встраиваются в психику человека. Давать же оценку своему поведению и своим мыслям человек начинает, когда сталкивается с мыслями и поведением, противоречащими его взглядам.

Согласно С. С. Арнольди, источником нравственных норм являются разнообразные жизненные наблюдения, которые подвергаются индукции и превращаются в систему взглядов и поступков. С. С. Арнольди также пишет о людях, которые сознательно ставят перед собой благородные цели, например принести счастье людям. По нашему мнению, их можно назвать либо утопистами, если их идеи не покидают кабинетов, либо опасными идеологами, поскольку желание принести счастье всем, вспомнить любую революцию.

Говоря о психических истоках моральности, уместно вспомнить 3. Фрейда, который, бесспорно, являлся выдающимся знатоком психологии людей. Фрейд много внимания уделял поиску морально-этических императивов. И хотя специальной работы, посвященной проблемам нравственности, у него нет, все же вся его доктрина постоянно «наталкивалась» на них, поскольку невозможно исследовать внутренний мир человека и обойти эту сферу. При этом, говоря о морали и нравственности, Фрейд скорее имел в виду общественную мораль, а не естественный нравственный закон как универсалию.

Ученый ставил вопрос: добр человек по своей природе или зол? ${ }^{2} \mathrm{He}$ будем говорить о выводах Фрейда, укажем только то, что для него объектом исследования стала «темная» сторона человека. В человеке он обнаруживает «скрытое дурное начало»³. Природная сексуальность про-

${ }^{2}$ См.: Лейбин В. Фрейд, психоанализ и современная западная фрилософия. М., 1990. C. 155.

${ }^{3}$ Там же. С. 156. 
тивостояла моральности, а следовательно, правовым, религиозным и моральным началам, принятым в обществе. По Фрейду, человек противопоставлен обществу, поскольку оно основано на этических требованиях, нравственных предписаниях, которые объективируются в религии и праве. Жизнь человека - это постоянные удары о барьер, поставленный обществом. Первые запреты - «табу» - возникли в очень далекие времена истории развития человечества и в измененном виде сохранили свою значимость во внутренне-душевной жизни современного человека в виде категорического императива, обоснованного И. Кантом ${ }^{4}$. Сам Фрейд, к слову, критически относился к современным ему нормам нравственности. В частности, он подвергал критике «двойную» мораль для мужчин и для женщин. Конечно, конкретные нормы общественной морали не вечны, со временем они претерпевают существенные изменения. Основной вектор развития морали - установление сбалансированной и разумной свободы и правового равенства.

Многие критиковали Фрейда (в частности, его ученик К. Юнг), и концепция его была принята далеко не полностью. К тому же в данной статье не ставится цель рассуждения об учении Фрейда, его последователях и критиках. Заметим только очевидный факт, что общество всегда быстро и болезненно реагировало на появление тех доктрин, в которых оно видело угрозу своего разрушения. Так, были осуждены софисты с их дионисийским началом. Официальное христианство боролось с гностиками. Такая же судьба была у Макиавелли, который хоть и не был официально осужден, все общество критиковало его идеи.

Однако вернемся непосредственно к теме нашей статьи - соотношению морали и права. Данное соотношение можно охарактеризовать как взаимность, более того, имеет место взаимопроникновение. Здесь возникает наболевший вопрос: какая нормативная система является первичной, и какая из них играет более значимую роль в жизни человека и общества. Соотношение права и морали является предметом нескончаемых научных дискуссий, которые стали частью не просто филлософрии и права, но и всего общественного сознания. При этом, как пишет А. А. Гусейнов, «допустимая общественно приемлемая мера расхождения между ними величина подвижная, которая меняется от эпохи к эпохе, от народа к народу, от поколения к поколению, от государства к государству» ${ }^{5}$. Выдающийся русский фолософ И. А. Михайловский в своей работе «Очерки фрилософии права» (Томск, 1914) писал, что вопрос о праве и морали можно свести к четырем позициям:

1. Между моралью и правом нет никакой разницы по содержанию. Любая моральная норма может быть облечена в правовую форму и стать нормой права. А вот реально будет ли придана нравственности правовая форма, зависит от целесообразности, в том числе от тех задач и целей,

${ }^{4}$ См.: Там же. С. 162.

${ }_{5}^{5}$ Гусейнов A. A. Мораль и право : линия разграничения // Lex Russika. 2018. № 8. URL: ps://cyberleninka.ru/article/v/moral-i-pravo-liniya-razgranicheniya 


\section{Вестник ВГУ. Серия: Право}

которые ставит перед собой государство и право. К этому примыкают психологические теории.

2. Право и нравственность суть автономные друг от друга регуляторы. Источник формирования права не есть тот же самый, что и для нравственности. То есть право и мораль не имеют ничего общего.

3. Право и нравственность - безусловно, родственные друг другу нормативные системы. Более того, право есть минимум нравственности, это те нормы, соблюдение которых позволяет быть обществу стабильным и жизнеспособным.

4. Право и нравственность различны по природе. Право является регулятором внешнего поведения людей, где принуждение - способ гарантии следования требованиям права. Мораль же обращается к внутреннему миру человека. Она требует внутренней преданности, делит людей на своих и чужих.

Что касается гарантий, то, наряду с голосом совести, большое воздействие на человека оказывают определенные негативные последствия со стороны моральной общности, к которой принадлежит человек.

Надо сказать, что в российской традиции мораль и право предстают как несовпадающие, а подчас противопоставляемые друг другу нормативные системы. Это чувствуется в современной России, хотя нередко такое противопоставление противоречит логике. Например, можно услышать из СМИ, из высказываний политиков и общественных деятелей, что права человека должны соблюдаться до тех пор, пока это не противоречит моральным устоям. Такая позиция неверна, поскольку именно мораль требует защиты человека и его прав. На протяжении развития учения о правах человека имелось в виду, что их соблюдение и защита отождествляются с добром и нравственностью.

А. А. Гусейнов приводит утверждение о том, что «легитимность права обеспечивается его соответствием требованиям морали» 6 . Но проблема в том, что мораль - это очень сложная и часто ускользающая материя. Она очень тяжело идентифицируется, поскольку не есть гомогенное явление: она многозначна, многоуровнева, склонна к изменениям. И именно в связи с этим следует обратиться к возможному существованию естественного нравственного закона, где обозначены метаморальные и метаправовые положения, которые отличаются всеобщностью, объективностью и неизменностью ${ }^{7}$. Вопрос о соотношении права и морали может представлять собой, во-первых, проблему соотношения права и актуальной общественной морали; во-вторых, права и нравственности в смысле естественного нравственного закона. По ходу рассуждений мы будем обращаться к соотношению актуальной общественной морали и так называемой метанравственности.

А. А. Гусейнов считает, что «общественная мораль и право в целом, если брать их тип взаимосвязи, ссылаются друг на друга», но все же ка-

\footnotetext{
${ }^{6}$ Гусейнов А. А. Указ. соч.

${ }^{7}$ Изменения могут происходить, но очень и очень постепенно.
} 
ждая из этих нормативных систем претендует на то, что может самостоятельно отрегулировать общественные отношения, даже если другая (гипотетически) будет упразднена ${ }^{8}$. Ученый пишет: «Как говорили древние философы, если даже отменять все законы, это не повлияет на поведение мудреца, так как он руководствуется нравственными соображениями и сам несет в себе критерий должного поведения. Мудрецу не нужны законы» ${ }^{9}$. В то же время активные приверженцы прав в XVII-XVIII вв. утверждали, что можно построить такую систему правового регулирования, которая будет работать даже если общество погрязнет в имморализме. Надо сказать, что на Западе это во многом удалось. Так, все согласны с тем, что механизм правового регулирования и работа государственного аппарата, основанная на праве, будет работать с равной эффрективностью, независимо от моральных и личных качеств тех, кто стоит у власти. В России, конечно, такой механизм не отработан, и для народа очень важны личные качества главы государства (или главы правительства в зависимости от формы правления), и именно личные качества властьимущих, а не право являются главной надеждой народа.

В процессе развития общества (эти процессы имеют место и в России) постепенно складывалась и укреплялась вера в правовое начало, в то, что право - это разумный и эффрективный регулятор общественных отношений, более того, именно право способно защитить и реализовать свободу и права личности. Сегодня нет таких общественных отношений, которые были бы табуированы для права ${ }^{10}$. Предмет правового регулирования стал предельно широк. Если еще вчера семейные отношения, в частности отношения родителей и детей, представляли собой предмет спора: может ли право вторгаться в эту область, то сейчас этот вопрос однозначно решен в пользу права, хотя некоторые консерваторы, особенно религиозные представители, все же негативно относятся к такому широкому правовому регулированию семейных отношений. А. А. Гусейнов вообще приходит к выводу о том, что «...вопрос о взаимодополняющем соотношении права и морали бесспорен по причине, что в ней (морали) нет звеньев (участников), которые не поддаются правовому регулированию». И далее: «...при таком подходе проблема отношения морали к праву перемещается в центр философрско-этических размышлений. Это позволяет этикам воспользоваться методологическим приемом из арсенала юридического знания и рассмотреть понятие морали через призму права, осмыслить ее как не-право, подобно тому, как юристы определяют право сквозь призму морали, описывают его как не-мораль» ${ }^{11}$.

Следует сказать, что особенно остро вопрос о разграничении права и морали был поставлен в первой половине XIX в. и вошел в круг самых обсуждаемых проблем. Причем дискуссии были достаточно сложными,

\footnotetext{
${ }^{8}$ См.: Гусейнов А. А. Указ. соч.

9 Там же.

10 Термин использован А. А. Гусейновым.

${ }^{11}$ Гусейнов А. А. Указ. соч.
} 


\section{Вестник ВГУ. Серия: Право}

если не сказать запутанными. Р. Паунд, к работам которого мы обратились, назвал их юридическими штурманами, которые помогают избегать угрозы кораблекрушения ${ }^{12}$.

Проблемы соотношения права и нравственности входили в круг базовых вопросов философии права, которая, к слову, возникла еще в то время, когда право, обычаи, нравственность, религия не были разграничены и дифрференцированы.

В Античности и Средние века право изучалось как нечто идеальное. Отыскивалось то, каким оно должно быть. Изучение практической юриспруденции в университетах предусматривалось в очень ограниченном формате. Например, римское право изучалось глоссаторами и постглоссаторами в университетах, но в практику внедрилось гораздо позже. В основе философии права лежали попытки обнаружить идеал права, к которому следовало относить правовые материалы Древнего Рима. Но истинное развитие, по мнению Р. Паунда, философии права началось тогда, когда был поставлен вопрос права и морали, когда «произошло усиленное вливание морали или этического обычая в право. Это привело к необходимости дать рациональное объяснение этого процесса при помощи выяснения степени схожести нравов и моральных норм» ${ }^{13}$. Р. Паунд выделяет еще другой фактор, который способствует усилению значимости философско-правовой мысли. Примерно в течение двух веков, которые предшествовали Реформации, юриспруденция была частью теологии, и разработки велись в русле школы естественного права, поэтому юридическая наука (не практика) рассматривалась как ветвь этики. Правовые нормы воспринимались как оформление нравственных норм, а если правовая норма противоречила духу нравственности, то она не приобретала правового характера и не имела юридической силы. Р. Паунд считает, что в первой половине XIX в. правовая наука значительно ослабла, и подачи Г. Еллинека (в России эта теория развивалась В. С. Соловьевым)

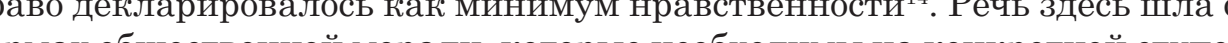

${ }^{12}$ Цит. по: Адыгезалова Г. Э. Социологическая юриспруденция в США в XIX веке : формирование доктрины, развитие и совершенствование правопорядка. СПб., 2012. С. 270.

13 Там же.

${ }^{14}$ См.: Еллинек Г. Социально-этическое значение права, неправды и наказания. М., 1910. Традиционно Г. Еллинека относят к школе юридического позитивизма и этатизма. Но этот мыслитель неоднозначен. П. Новгородцев в предисловии к вышеуказанному труду указывает на эклектичность взглядов Г. Еллинека (c. 6). URL: ttps://dlib.rsl.ru/viewer/01003767613\#?page=6 (см.: Соловьев В. С. Нравственность и право. История философии права. СПб., 1998). 
ни общественного развития. Имелась в виду конкретная мораль конкретного общества. Г. Еллинек писал, что «великие социальные силы: религия, мораль, общественные нравы, словом, вся совокупность культурных факторов и обусловленные ими общественные интересы и общественные различия непрерывно воздействуют на построение и развитие права и дают сильнейшую, только совершенствуемую другими фракторами гарантию ее действительности» ${ }^{15}$. Право рассматривалось им как часть морали. Мораль, т. е. этические обычаи, являлась гарантией общественного порядка. Исходя из этого, право является частью макронормативной системы, обеспечивающей социальный порядок. Если говорить о морали в чистом виде, то она есть то, что возвышается над минимумом, обеспечиваемым правом, и является нравственностью в высоком смысле.

Сторонники неокантианства (Р. Штаммлер, Г. Риккерт, В. Вильденбанд) считали, что право - орудие, инструмент справедливости. То есть право воспринималось как естественное право с изменчивым содержанием, но имеющее в своем основании неизменную константу ${ }^{16}$.

Сторонники неогегельянства (Б. Кроче, Дж. Джентиле, А. Кожев) утверждали, что право и мораль должны способствовать достижению цели, а именно построению идеальной цивилизации. С их точки зрения, право подчиняется морали, но при этом право и мораль всегда детерминированы историей конкретных обществ, а следовательно, с необходимостью обусловливаются временем и местом ${ }^{17}$.

Рассматривая историю взглядов на соотношение права и нравственности, Р. Паунд обращается к аналитической юриспруденции, отличительной чертой которой является то, что она настаивает на автономии юридической науки. Представители ее отрицали наличие неправовых оснований права и считали, что надо воспринимать и изучать право таким, какое оно есть, анализировать актуальные правовые реалии, в частности нормы и институты. Именно они и составляют предмет рефлексии правовой науки. Правовая наука должна изучать «чистое» право, в смысле «очищенное» от неправовых элементов. Вопрос о том, каким право должно быть, выходит за рамки правовой науки. Следовательно, аналитическая юриспруденция жестко разграничивала право и мораль. Однако представители ее соглашались с тем, что суд при рассмотрении конкретных дел мог включить в механизм принятия решений нормы морали. То есть в практической сфере применения права мораль вовсе не отвергалась. Р. Паунд подвергал критике аналитическую юриспруденцию. Право формируется в процессе деятельности и законодательных, и судебных органов (речь идет об американской правовой системе), но различия между ними в том, что суды вынуждены в обоснование своих решений полагать мораль и этику. В результате включения моральных норм в решении суда появлялись новые нормы права, когда «нельзя най-

\footnotetext{
${ }^{15}$ Цит. по: Адыцезалова Г. Э. Указ. соч. С. 230.

${ }^{16}$ См.: Там же.

${ }^{17}$ См.: Там же.
} 


\section{Вестник ВГУ. Серия: Право}

ти подходящее правовое предписание среди уже существующих норм»18. По мнению представителей аналитической юриспруденции, право должно быть настолько полным, что суду необходимо отыскивать уже существующую правовую норму и применять ее, не прибегая к неправовым средствам. Процесс имеет формально-механический характер. В случае если невозможно было найти соответствующую правовую норму (но это исключительный случай), то суд мог обращаться к морали и этике. Но включение этих норм в обоснование судебного решения должно быть минимальным. По мнению позитивистов, такие правила вынесения решения обеспечивали беспристрастность судебных постановлений.

Однако внедрение этого принципа на американской почве потерпело неудачу. Правовые стандарты сами по себе формировались из моральных принципов: например, добросовестная конкуренция, презумпция честности доверенного лица, выполнение условий договора должным образом и т. д. Все эти принципы имеют нравственное основание. Существуют также и интуитивные чувства судьи, которые складываются из моральности и справедливости. Таким образом, Р. Паунд был уверен, что судебный процесс никогда не станет набором механических стадий, а решения никогда не будут выноситься на основе чистого набора правовых норм, квалифицирующих фракты.

Кроме того, существует институт судейского усмотрения, который имеет место и в странах романо-германской правовой семьи. Это относится и к России, где рассматриваются такие категории дел, когда право нуждается в этической и моральной поддержке. Например, дела о лишении родительских прав. В таких делах судья точно не сможет оставить в стороне собственные моральные убеждения и чувство справедливости.

Таким образом, Р. Паунд доказал, что доктрина аналитической юриспруденции может существовать в виде теоретических положений, но практическое ее применение оказывается невозможным ни на англоамериканской, ни на романо-германской почве. В еще большей степени это относится к азиатским странам, которые формально живут по западным образцам (Республика Корея, Япония). Внутренняя мораль в этих странах в процессе правоприменения играет ведущую роль, поскольку именно моральные нормы являются традиционными регуляторами общественных отношений.

Другой не менее известный американский мыслитель Р. Дворкин также считал, что право и мораль (в смысле актуальная общественная мораль) тесно связаны между собой. И «связаны между собой не естественным образом, а эпистемологически. Иначе говоря, право может быть нравственным, если существует практика обсуждения принципов и законов» ${ }^{19}$. Р. Дворкин также обращается к судебной практике (речь идет о британской и американской правовой системе). Он так же, как и Р. Па-

\footnotetext{
${ }^{18}$ Цит. по: Адыгезалова Г. Э. Указ. соч.

${ }^{19}$ Hепогодий A. B. Р. Дворкин. О правовой концепции P. Дворкина. URL: http// www.tronsnab.r/ronald-dworkin - o pravovoy kocepcii R. Dworkina
} 
унд, считает, что судьи, принимая решение, включают в сферу мотивации как правовые нормы, так и субъективные убеждения, которые могут быть юридическими (правосознание, чувство справедливости) и моральными. При рассмотрении дела и принятии решения судьи прорабатывают как юридическое, в частности судебную практику, так и моральное, создавая из этих нормативных структур единую целостность.

Р. Дворкин считает, что любая правовая норма подлежит толкованию. Толкование при этом не преследует цели познания истинной воли законодателя, но встраивается в структуру убеждений и ценностей интерпретатора. Причем «каждый толкователь включает в процесс толкования устойчивые ценности, принятые в обществе. Решение судьи обусловливается большим количеством мотивов: эмоции, воззрения, переживания. Судебное решение выносится в соответствии с принципами судьи» ${ }^{20}$. При вынесении решения судья рассуждает о справедливости с морально-этической и политической точек зрения. Следовательно, право всегда содержит элементы морали, так как все правовые суждения считаются оценочными. Однако Р. Дворкин не исключает, что созданные таким образом судебные акты могут оказаться ошибочными. «Не всегда единственно правильное моральное решение и моральное убеждение является достаточным критерием для вынесения судебного решения» ${ }^{21}$.

Р. Дворкина часто относят к представителям естественно-правовой теории, но сам ученый называет свою концепцию интерпретационной концепцией права, а также естественным позитивизмом.

С точки зрения разработанной им интерпретационной теории право неотделимо от морали, так как все правовые суждения являются оценочными. Судья в связи с этим должен руководствоваться тремя принципами: процедурностью, честностью и справедливостью. И задача судьи при вынесении решения - поиск целостности, состоящей из моральных ценностей и норм позитивного права, что гарантирует справедливое и правовое разрешение дела. Кроме того, судья «должен представить право в лучшем свете, в смысле морального и политического совершенства, выражающегося в правилах и принципах справедливости, в частности равенства соблюдения судебного процесса и индивидуальных прав» ${ }^{22}$. Именно практика показывает, что позитивное право наполнено моральным содержанием.

Приведенные выше рассуждения и анализ концепций ученых показывают, что отправной точкой в вопросе о соотношении морали и права является тип правопонимания. Р. Дворкин понимает право как целостность, которая включает в себя и законодательство, и юридическую практику. Последняя не тождественна праву. Она входит в него, но не заполняет его полностью. Другие элементы права - практика по реализации законодательных норм, толкование, чувство справедливости, мораль, об-

\footnotetext{
20 Там же.

21 Там же.

22 Там же.
} 


\section{Вестник ВГУ. Серия: Право}

щественное сознание в целом. Судья при вынесении решения вправе и должен использовать все эти элементы, что обеспечивает правильность и полноту разрешения дела.

Но среди ученых-правоведов остаются сильны и позитивистские позиции, в частности позитивистская теория Г. Л. А. Харта, англо-американского правоведа, оказавшего сильное влияние на молодого Д. Роулза. Г. Харт внес большой вклад в разработку теории методологии юриспруденции ${ }^{23}$. Метод Г. Харта заключался в соединении традиций аналитической философии XIX в. с концепцией Дж. Бентама ${ }^{24}$. Ученый находился под сильным влиянием Дж. Остина, кроме того, серьезно изучал труды фрилософа-лингвиста Л. Видгенштейна. Следуя концепции последнего, он стал применять лингвистический метод в юриспруденции. То есть Г. Харта нельзя назвать чистым позитивистом, поскольку он не воспринимает командную теорию права (Дж. Остин), считая, что право гораздо сложнее. Концепция Г. Харта во многом схожа с утилитаристской позицией Дж. Бентама.

По Г. Харту, связь между моралью и правом выявляется при изучении, толковании и применении норм в конкретных ситуациях, когда спорным становится сам смысл закона. Эта взаимосвязь также просматривается, если «мы расширяем свою точку зрения и спросим не о том, требуется ли соответствие моральному минимуму каждой отдельной нормы закона для того, чтобы он был законом, а о том, может ли система правил в своей совокупности соответствовать данному требованию, быть правовой системой» ${ }^{25}$. Для ответа на этот вопрос, по Г. Харту, необходимо иметь в виду три доктрины понимания права:

1) аналитическая юриспруденция как метод изучения права путем постижения смысла и толкования правовых норм. При этом исследуется и толкуется огромный словарный запас юриспруденции ${ }^{26}$. Харт считает, что изучение сферы правовой лингвистики является одним из способов познания сущности права;

2) командная теория права, согласно которой право есть не что иное, как команда легитимной власти;

3) утилитаризм, который судит о правильности или неправильности любых поступков по их предполагаемой значимости для благополучия людей ${ }^{27}$.

Все три доктрины - аналитическая юриспруденция, утилитаризм, командная теория - составляют целостную картину права. По этому по-

${ }^{23}$ См.: Баженова Е. А. Философия права Г. Л. А. Харта. Владимир, 2016.

${ }^{24}$ Английский философ, родоначальник утилитаризма (1748-1832).

${ }^{25} \mathrm{Xapm} \mathrm{Г.} \mathrm{Л.} \mathrm{А.} \mathrm{Позитивизм} \mathrm{и} \mathrm{разграничение} \mathrm{права} \mathrm{и} \mathrm{морали} \mathrm{//} \mathrm{Правоведе-}$ ние. 2005. № 5. С. 124.

${ }^{26}$ Английская и американская юриспруденции включают в себя множество формул и терминов, имеющих собственное значение, отличное от обыденного.

${ }^{27}$ Об утилитаризме и морали см.: Заладина M. В. Моральная составляющая утилитаристских концепций. URL: https://cyberleninka.ru/article/n/moralnayasostavlyayuschaya-utilitaristskih-kontseptsiy 
воду Г. Харт пишет: «...можно одобрять разделение права и морали, признавая важность аналитических значений юридических концептов, и в то же время предполагать, что сущность права - в команде. Одним из источников путаницы в критике разграничения права и морали было убеждение в том, что ложность одной из этих доктрин свидетельствует о ложности других. Так, например, многим критикам не доставало ясности мысли: они полагали, что постепенное проявление несоответствия командной теории было бы достаточным для того, чтобы показать неправильность отделения права и морали» ${ }^{28}$. Конечно, считает Г. Харт, закон становится законом только тогда, когда он основывается на принятых в обществе «фундаментальных правилах процедуры принятия такого рода нормативных актов» ${ }^{29}$. То есть, по Г. Харту, не морально-этические обоснования делают закон таковым, а соблюдение установленных процедур его принятия. При их соблюдении закон становится законом независимо от его морально-этического содержания. При этом само наличие таких процедур свидетельствует о том, что право - это не команда власти. В демократической стране сувереном является народ. Он избирает своих представителей в различные легислатуры, чьи команды должны соответствовать воле избирателей. Это подтверждает то, что мораль вовсе не отторгается, просто она не является критерием разграничения правового и неправового. Для того чтобы нормы обрели характер правовых, необходимо, чтобы власть была легитимна, а процедуры, необходимые для принятия закона, соблюдались.

С критикой позитивизма выступил американский ученый Лон Фуллер. В статье «Позитивизм и верность праву» он вступил в дискуссию с Г. Хартом, подвергая критике положения его концепции. Кроме того, он изложил свои мысли в книге «Мораль права», переведенной на русский язык и изданной в 2007 г. Л. Фуллер критикует попытки позитивистов сформулировать концепцию нейтрального права, в которой за скобки выводятся мораль и справедливость. Он критикует позицию, в соответствии с которой «норма права просто означает существование публичного порядка» ${ }^{30}$. Это означает, что право представляет собой организованное правление, действующее посредством различных инструментов и каналов юридически оформленного управления. В этом смысле все современные общества живут в условиях верховенства права, в том числе авторитарные и радикально-религиозные режимы (Северная Корея, Саудовская Аравия) ${ }^{31}$. Л. Фуллер совершенно не согласен с этим утверждением. Действительно, те нормы, которые были приняты в нацистской Германии, однозначно не считаются правовыми. Он критикует также

28 Там же. С. 124.

29 Там же.

${ }^{30}$ Цит. по: Фридман Д. В. Порядок в праве. Какое отношение экономика имеет к праву. М., 2017.

${ }^{31}$ См. еще об этом: Щеглов Э. Ф. Два типа морали Лона Фуллера. URL: https:// cyberleninka.ru/article/n/dva-tipa-morali-lona-fullera 


\section{Вестник ВГУ. Серия: Право}

определение, данное антропологами права: социальная норма является правовой, если пренебрежение ею или ее несоблюдение регулярно вызывает фактическое применение или угрозу применения физической силы со стороны индивида или группы, обладающих привилегией делать это» ${ }^{32}$. Л. Фуллер считает, что фраза о применении «физической силы к лицам нарушителям права, причиняет вред не только практике, но и науке, затуманивая ясность мысли о назначении и функциях права» ${ }^{33}$. Он абсолютно отвергает позицию о присутствии силы, которая входит в традиционный перечень признаков самого права. Ученый справедливо пишет о том, что «гражданин не может руководствоваться в своих действиях правом, когда то, что называется правом, предстает как ряд спорадических и бессистемных применений государственной власти» ${ }^{34}$. Л. Фуллер, рассматривая природу морали, выделяет два типа ее обоснования и, соответственно, два типа подхода к ее сущности и истокам. Первый означает, что мораль основана на чувстве долга, Л. Фуллер так и называет ее - мораль долга. Она может проявляться в патриотизме, готовности пожертвовать всем ради выполнения долга. Причем «идеология патриотизма - предмет внимания и заботы государства, вернее, действующего государственного строя, правящего политического режима. И чем он будет жестче тем категоричнее будут моральные законы» ${ }^{35}$. Мораль, навязанная обществу, изначально является чьими-то личными убеждениями, которые становятся убеждениями всего общества, а члены общества постепенно воспринимают их как свои собственные. В этом случае мораль предстает как идеология, которая, проникая в сознание индивидов, воспринимается ими как их личные убеждения. Одновременно власть следит, чтобы не оставалось поля для формирования собственных, отличных от официальных, убеждений. Но такая общественная мораль может наталкиваться на иную мораль - ту, которая складывается параллельно официальной идеологии, что может быть связано с индивидуальным поиском истины. П. Я. Чаадаев написал по этому поводу: «...прекрасная вещь - любовь к отечеству, но есть еще нечто более прекрасное - это любовь к истине. Любовь к отечеству рождает героев, любовь к истине создает мудрецов. Любовь к родине разделяет народы, питает национальную ненависть и подчас одевает землю в траур, любовь к истине распространяет свет знания, создает духовные наслаждения, приближает людей к Божеству» ${ }^{36}$. Мораль долга - это базовые нормы, и исток их в древних запретах «табу», о которых уже говорилось. Мораль долга у Л. Фуллера не имеет негативной коннотации, она необходима для обеспечения стабильности и безопасности. Это своеобразный минимум, жизнеобеспечивающий фрун-

${ }^{32}$ Цит. по: Фуллер Л. Позитивизм и верность праву. Ответ профессору Г. Харту // Правоведение. 2005. № 6. С. 136.

33 Там же.

${ }^{34}$ Там же. С. 140.

${ }^{35}$ Щеглов Э. Ф. Два типа морали Лона Фуллера.

${ }^{36}$ Там же. 
дамент общества. Второй тип морали - мораль стремления. Л. Фуллером она воспринимается как «мораль восхождения», «мораль к совершенству» и предполагает вариативность и креативность и, конечно же, является моралью более высокого типа, чем мораль долга, так как способствует реализации человеческого потенциала. Оба типа включаются Л. Фуллером в право, хотя мораль стремления все же более близка к эстетике, т. е. к «идеалу чувственного отношения к миру, к прекрасному. Она проникает в право не прямым образом, не через «конкретные дозволения, обязанности и запреты, а через определение общей картины человеческого прогресса, как «поиск высших социальных ориентиров, формирование внешних для права критериев» ${ }^{37}$. Мораль стремления мотивирует законодателя к формированию справедливых и моральных законов. Интересно, что мораль долга у него более соответствует государству, а мораль стремления - праву.

Рассматривая проблему о соотношении морали и права, Л. Фуллер не мог обойти вопрос о естественном праве. Ученый отрицал метафизический характер естественного права и не считал его Высшим законом. Наоборот, если говорить о вертикали, то естественное право является низшим законом. Например, оно походит на «естественные законы, которые уважает плотник, желающий, чтобы возводимый им дом остался стоять и служить тем, кто в нем живет» ${ }^{38}$. Такое отношение к естественному праву, однако, не бесспорно. Смысл, который вкладывает Л. Фуллер в естественное право, не отражает его сущности. У него оно походит на психологическую интуицию и рассудок, в соответствии с которыми могут создаваться нормативы. Естественное право - это те нормы, которые изначально присутствуют в разуме людей и открываются ими в результате сторонней оценки различных ситуаций и их разрешения. Фулллер говорил о внешней морали права, но, по сути, это и есть естественное право.

Фуллер вводит понятие процедурности естественного права, которое он именовал внутренней моралью права. «В этом смысле то, что я назвал внутренней моралью права, является процедурной версией естественного права. Термин «процедурный» указывает на то, что нас интересуют не материальные юридические нормы, а способы, посредством которых должна разрабатываться и проводиться в жизнь система норм для управления человеческим поведением, чтобы она была действенной и в то же время оставалась, какой была задумана» ${ }^{39}$. Внутренняя мораль права беспристрастное соблюдение всех процедур.

Вышеуказанные рассуждения позволят нам перейти к вопросам о естественном праве и метафизике. В Европе в конце XIX в. вопрос о единстве и различии права и морали являлся одним из главных вопросов философского дискурса. При этом представители школы естественного права рассматривали его как элемент единства нормативно-ценностных

\footnotetext{
37 Там же.

38 Фуллер Л. Указ. соч.

${ }^{39}$ Там же.
} 


\section{Вестник ВГУ. Серия: Право}

закономерностей. Социальная реальность есть часть всеобщего мироустройства, а естественное право, соответственно, часть всеобщемировых нормативов. То есть налицо метафизическое восприятие естественного права, которое «не соотносится ни с каким законодательством, а имеет религиозно-интенциональные основания, которые углубляют и объективируют его юридический смысл, связывают его с всеобщим мировым континуумом человеческого бытия» ${ }^{40}$. Позитивизм, как уже говорилось, старался «освободить» право от связи с моралью ${ }^{41}$. Это особенно характерно для французской философии права 1920-х гг. В. Лезьер пишет, что сторонники позитивизма «не замечали, что к догматизму и косности барьеров приводит их демонстрация убеждений, предупреждающих о строгости барьеров, которые должны быть установлены между правом и моралью. Их постулаты основывались на принципе исключения противоречия между религиозными и светскими ценностями, так как мораль, по их мнению, истоками уходит в религию, а ценности Республики (имеется в виду Французская республика) - это демонстрация светскости» ${ }^{42}$. Жесткое разделение права и морали позволит судьям избежать путаницы в обосновании решения.

Однако позже многие ученые все же высказались в пользу того, что границы между правом и моралью вовсе не так строги, как утверждают позитивисты, и что право все же содержит в себе идею нравственности. Более того, сформировалось течение правового морализма, отличавшегося уж совсем радикальными убеждениями ${ }^{43}$. Так, по мнению его представителей, если закон не отвечал нравственным принципам, то он вообще не имел права называться таковым. Причем, как замечает В. Лезьер, данное требование не ограничивалось общими началами, принципами права: нравственным содержанием должна быть наполнена каждая норма. Моралисты, образно выражаясь, «вгрызались» в само тело закона, и поэтому движение стали называть не просто правовым, а законническим морализмом ${ }^{44}$.

И вот мы подошли к очень важному вопросу: каково соотношение морали и нравственности? Почему рассматриваем эту проблему именно сейчас? Дело в том, что именно в последние 30-40 лет появились дискуссии, проходящие в русле постмодернистского взгляда на реальность,

88 касающуюся свойств морали, нравственности и права. До этого времени утверждение о необходимости закрепления морали в праве указывало на необходимость обоснования права с точки зрения высшего нравственного закона. Но ситуация постмодерна изменила постановку вопроса. Нрав-

40 Лезьер В. Коллизии права и морали в западной правовой традиции // Вестник Моск. гос. областного ун-та. Серия «Юриспруденция». 2018. № 1. С. 28.

${ }^{41}$ Оговоримся, что речь идет о научном понимании права и поиска его определения.

42 Лезьер В. Указ. соч.

${ }^{43}$ Наиболее яркий представитель - Патрик Девлин, английский юрист, судья (1905-1992).

${ }^{44}$ См.: Лезьер В. Указ. соч. С. 29. 
ственность - это действительно высший закон, часть мироздания, в которое входит человек, общество, государство и право. Но существует также понятие общественной морали, свойственной конкретной уникальной группе. Этому посвящает свои рассуждения Ю. Хабермас. Он пишет, что существуют три точки зрения по этому вопросу. Первая - так называемая аристотелевская позиция, вторая - кантовская и третья - утилитаристская позиция ${ }^{45}$. Можно также говорить об этике сострадания. Все остальные теории есть синтез трех указанных подходов.

Аристотель - сторонник свободной воли; а поскольку природа человека более возвышенна, чем, например, природа животного, то цели он ставит перед собой тоже возвышенные. Аристотель составил иерархию целей, к которым, прежде всего относятся философия и политика. Мораль же распространяется на всех, но на ее реализацию влияет положение человека в обществе (речь идет о рабстве).

Но если, по Аристотелю, человек в соответствии со своей свободной волей вынужден сам принимать решения, то Кант, с точки зрения Ю. Хабермаса, освобождает человека от необходимости самому принимать решения. Кант вводит максимы, тем самым направляя человека по определенному пути ${ }^{46}$. Моральные заповеди оказываются категорически обусловленными императивами. Смысл их позволяет принять в качестве долженствования то, что может не зависеть от личных целей и предпочтений, если они вообще сформированы у человека. Кант, по мнению Ю. Хабермаса, лишил человека собственной воли, на которой настаивал Аристотель. По нашему мнению, императивы Канта и хотя бы минимальное следование им - это условие выживания человека в обществе, основы выживания самого общества и, наконец, основа того, чтобы человек оставался человеком. Ведь в истории уже были случаи, когда софисты, эти проводники культуры разрушения, выступили против тех обычаев и нравственных максим, которые они рассматривали как путы для человека. Общество очень быстро осознало опасность таких воззрений и отвергло их. Гораздо позже Н. Макиавелли заговорил об отказе от моральных устоев, когда речь идет о политике, но общество, оценив масштабы его трудов, все же осудило такие воззрения. Из этого можно сделать вывод, что наши максимы встроены в сознание людей, они означают свободу и благо. Но что говорит Ю. Хабермас? Конечно же, он далек от Макиавелли. Хабермас предлагает прервать «само собой разумеющиеся данности привычной конкретной нравственности» ${ }^{47}$ и вызвать к жизни морально-практические дискурсы. Он хотел бы дистанцироваться от тех жизненных контекстов, с которыми «сплетена наша собственная самотождественность» ${ }^{48}$. Ученый говорит о таком дискурсе,

${ }^{45}$ См.: Хаберлас Ю. Демократия. Религия. Нравственность // Моск. лекции и интервью. М., 1995.

${ }^{46}$ См.: Там же. С. 17.

${ }^{47}$ Там же. С. 23.

48 Там же. 


\section{Вестник ВГУ. Серия: Право}

в котором могли бы принимать участие заинтересованные люди со своими аргументами. Он должен основываться на позиции беспристрастности, где каждый может присоединиться к своей группе. По мнению Ю. Хабермаса, этот морально-практический дискурс означает «идеальное расширение самого нашего коммуникативного сообщества, а нормы, предлагаемые на обсуждение, могут быть обоснованы и одобрены лишь в том случае, если они отвечают интересу всех, кого они касаются. Следовательно, значение дискурсивно-обоснованных норм имеет двоякое значение: в каждом конкретном случае они позволяют выяснить, что именно является равным интересом всех, а также выражают общую волю, вобравшую в себя волю всех без всякого обоснования» ${ }^{4}$. Для Ю. Хабермаса такой дискурс не есть какое-то теоретическое построение, это юридическая практика, прежде всего диалог народа и власти, выражающийся в обсуждениях, слушаниях, референдумах, консультациях. На первый план должны выходить живые ситуации, а не вечные застывшие императивы. Ю. Хабермас пишет: «Наше истолкование категорического императива с позиций теории дискурса позволяет увидеть односторонность той теории, которая концентрируется исключительно на вопросах обоснования. Пока и поскольку моральные обоснования опираются на принцип всеобщего, а этот принцип принуждает участников дискурса рассматривать дискутируемые нормы в отрыве от конкретных ситуаций, невзирая на мотивы и существующие институты, выясняя лишь то, что могут ли они вообще найти разумное обоснование и одобрение со стороны всех заинтересованных» ${ }^{50}$. Ю. Хабермас отрицает всеобщность таких принципов, поскольку не существует стандартных ситуаций, где общее совпадало бы с конкретным. Более того, немецкий ученый в некотором смысле упрекает Канта в формировании чувства вины в челове-

м ке, поскольку кантовские максимы имеют значение независимо от того, 일 выполняет их человек, находящийся в конкретной ситуации, или нет. Z Максимы всегда имеют обязывающую силу. И если человек оказывается 尺े в ситуации, в которой он просто не в состоянии выполнить моральный ㄱ долг, то ему предстоит мучиться угрызениями совести: «...то, что основания, корректирующие такую претензию на значимость, не остаются бездействующими, явствует из угрызений совести, которые мучают нас, когда мы поступаем вопреки известному нам велению долга. Чувство вины - доступнейший индикатор измены долгу» ${ }^{51}$. Ю. Хабермас предлагает разбить основы всеобщих принципов и оставить только те, которые подходят под контекст ситуации. По его мнению, не стоит воспринимать всеобщие принципы как нечто трансцендентное или имманентное. Они имеют вполне рациональное обоснование и вырабатываются социальной практикой: деятельностью организаций, движений, политической борьбой, развитием частных жизненных укладов. Универсализм и всеобщ-

\footnotetext{
${ }^{49}$ Хаберлас Ю. Демократия. Религия. Нравственность.

${ }^{50}$ Там же. С. 24.

${ }^{51}$ Там же.
} 
ность формируются как уважение к каждому и солидарность с каждым ${ }^{52}$. Процесс складывания всеобщих для конкретного социума норм достаточно растянут во времени и имеет конкретное авторство. Моральные высказывания на первых порах исходят от конкретных субъектов, чьи действия, возможно, скоординированы, а сами они связаны между собой. После имеет место интерсубъективное признание моральных норм или практик, которые для той или иной общности постепенно начинают восприниматься как истинные и обязательные к реализации правила поведения. В таком обществе субъекты знают, чего ожидать друг от друга. Как пишет Ю. Хабермас, «моральное высказывание потенциально содержит в себе основание оснований, которые могут быть актуализированы в моральных сфрерах ${ }^{53}$. Моральные правила действуют сами по себе, их сила проявляется в двух, связанных между собой ступенях интеракций. На первой ступени они непосредственно управляют социальным действием, определенным образом направляя волю субъектов. На второй - регулируют критические высказывания индивидов в конкретной ситуации. Мораль, во-первых, подсказывает как должен поступить субъект коммуникаций; во-вторых, она дает основания для достижения консенсуса, урегулирования конфликтов. При этом моральные нормы имеют подвижный характер.

Мысль Ю. Хабермаса, безусловно, весома и имеет практическое подтверждение. Вместе с тем хочется отметить, что подвижность моральных норм очень условна. Рассуждая об этом, надо помнить, что современность, в которой мы живем, - время поистине революционное. Начиная с промышленной революции, оно течет очень стремительно, становясь свидетелем невероятных изменений как в сфере технологий, так и социальной сфере. Общество очень быстро менялось и продолжает меняться. Это же касается и частного образа жизни. Но следует отметить, что столь стремительные изменения имеют место только со времени Промышленной революции, хотя некоторые считают, что отправной точкой можно назвать Вестфальский мир 1648 г. Если мы окинем взглядом историю, то поймем, что мораль не менялась тысячелетиями. Двадцатый век смело можно назвать разломом времени. В течение жизни одного человека происходили невероятные перемены. Они были вызваны как войнами, так и социальной инициативой. Пример тому - сексуальная революция, начавшаяся с конца 60-х гг. ХХ в. Но даже сейчас мораль прошлого имеет значительное влияние на сознание людей. По нашему мнению, свойство морали - это устойчивость, что присуще также религии. Говорить о морали как инструменте достижения консенсуса можно очень осторожно и с оговорками, поскольку функцию достижения консенсуса призвано выполнять право.

Современное общество - это общество без религии. Религия ушла из государственной сферы и стала частным делом. Церковь, безусловно,

\footnotetext{
${ }^{52}$ См.: Там же. С. 27.

${ }^{53}$ Там же.
} 


\section{Вестник ВГУ. Серия: Право}

обладает огромной значимостью, но именно как субъект гражданского общества или как политический актор. Мораль тоже не может быть рассмотрена в качестве публичной основы, а следовательно, «значимость социальных правил распадается» ${ }^{54}$. Это значит, что мораль потеряла основание и объяснение трансцендентальными началами в лице Бога. Социум отошел от тех правил, которые так долго его структурировали. Постсоветское общество - это люди, их дети и даже внуки, у которых сформировалось искаженное восприятие долга и стремления. Современная мораль имеет обоснование в разуме и благе индивидов, не поглощенных социумом. Ю. Хабермас справедливо говорит о постметафизике в моральной философии, которая находится в поиске нового обоснования моральных норм без обращения к религии. Заметим, что задача, прямо скажем, нелегкая. Ю. Хабермас рассуждает об этих основаниях (кстати, он вводит термин «моральный реализм») и пишет, что, «моральная норма не может быть объяснена устройством мира в целом» ${ }^{55}$. Для ценностных суждений, уподобляющихся высказываниям, обоснование может лежать в восприятии, возможности интуитивного постижения, идеального созерцания ценностей ${ }^{56}$. То есть, во-первых, мораль базируется на психологии и интуиции. Во-вторых, хотя ранее утилитаризм, хотя и предлагал принцип обоснования моральных суждений, все же, по замечанию Ю. Хабермаса, упускал из виду «индивидуальный смысл морали» ${ }^{57}$. В-третьих, повседневные моральные практики потерпели бы крах, «если бы их участники отказали бы своим моральным спорам в каком-то когнитивном содержании. В-четвертых, мораль взывает к авторитету подорванных в своей основе традиций, ради достигнутых или благоприятных, стабилизирующих моральное сознание результатов» ${ }^{58}$. То есть Ю. Хабермас хотя и против того, чтобы искать моральные обоснования в религии, все же не может не признать факта, что религия оказывается нужной.

Но если не религия, то что же в этом случае может служить обоснованием морали? Здесь Ю. Хабермас вводит понятия «воля» и «разум», которые имеют способность определять индивидуальную волю благородными максимами. Он приводит рассуждения о том, что принятое решение может быть оправдано на эпистемологических основаниях, т. е. согласно убеждениям лица или группы лиц, которые могут каким-то образом навязывать их обществу. И ценность моральных установок в конечном счете решает эпистемологический авторитет самого деятеля. Постепенно положение дел в интерсубъективном мире, рефлексия над практикой, над совместным опытом, различными сферами жизни «доводит до сознания

${ }_{54}$ Хабермас Ю. Вовлечение Другого. Очерки политической теории. СПб., 2008. C. 60

${ }^{55}$ Там же.

${ }^{56}$ Там же. С. 63.

${ }^{57}$ Там же. С. 65.

${ }^{58}$ Там же. 


\section{Теория и история государства и права}

некое этическое знание, которым мы сами еще располагали» ${ }^{59}$, поскольку наше сознание и убеждения сформированы благодаря эпистемологическому авторитету первого лица ${ }^{60}$.

Далее Ю. Хабермас пишет, что сознание имплицитного знания не тождественно познанию объектов или фрактов: «Познание движется против интуиции, тогда как рефолексивно достигаемые усмотрения эксплицируют дотеоретическое знание, вводят его в контекст, проверяют его значимость и практически зондируют. Этическое усмотрение возникает благодаря экспликации тех знаний, которыми объединенные в коммуникативное сообщество индивиды, уже обладают в силу их укоренения в культуре» ${ }^{61}$.

Ю. Хабермас предлагает разделить нравственность по горизонтали и по вертикали. «Если мы хотим учитывать коммуникативную беспристрастность моральных суждений и притязаний обязывающих норм на категорическую значимость, то должны отделить горизонтальную перспективу, в которой регулируются межличностные отношения, от вертикальной перспективы тех или иных жизненных проектов и дать самостоятельные ответы на вопросы подлинно морального характера. Абстрактный вопрос о том, что в равной мере представляет интерес для всех, превосходит контекстуально связанный этический вопрос, что является для нас наилучшим. Тем не менее сохраняет определенный смысл интуитивное понимание того, что вопросы справедливости вытекают из идеалистически расширенного толкования этических вопросов» ${ }^{62}$.

Присутствие благого в справедливости означает, что моральное сознание обусловлено определенным типом самопонимания моральных личностей. Они признают свою принадлежность к определенным моральным общностям, участники которых знают, что именно для них является благом. Такое утверждение справедливо не только для морали, но и для права. Закон тогда наполнен нравственной силой, когда он отзывается в перспективе каждого. Но такому условию отвечают именно универсальные законы. Поэтому в обществе и должен проходить дискурс, в котором принимает участие каждый, который становится в этом случае потенциальным законодателем. «Играя роль одного из законодателей, каждый принимает участие в некоем основанном на сотрудничестве предприятии, включаясь тем самым в интерсубъективную расширенную перспективу» ${ }^{63}$. Исходя из этого правовая норма может быть обобщена с точки зрения каждого участника ${ }^{64}$. Для этого, по Ю. Хабермасу, требуется ситуация обсуждения, где каждый обязан принимать точку зрения Другого, чтобы проверить, может ли та или иная форма быть желательна

\footnotetext{
59 Там же. С. 86.

${ }^{60}$ См.: Там же.

${ }^{61}$ Там же. С. 87.

${ }^{62}$ Там же. С. 91-92.

${ }^{63}$ Там же. С. 96.

${ }^{64}$ См.: Там же. С. 97.
} 


\section{Вестник ВГУ. Серия: Право}

для всех, с точки зрения каждого. Такова ситуация, нацеленная на достижение взаимопонимания рационального дискурса, в котором участвуют все заинтересованные лица. Обсуждаемая норма только в том случае может претендовать на значимость, если она получила одобрение со стороны всех участников практического дискурса ${ }^{65}$.

По мысли Ю. Хабермаса, именно дискурс оправдывает содержание морали равного обращения с каждым и солидарной ответственности за каждого ${ }^{66}$. Дискурс - это путь к достижению согласия. Участники общественных отношений как на макро, так и на микроуровне неизбежно оказываются втянутыми в конфликты, которые не должны решаться путем насилия или даже компромисса. Здесь необходимо полное взаимопонимание ${ }^{67}$. Конечно, это вопрос будущего. Будущий тип личности у Ю. Хабермаса будет узнан и признан другими людьми.

Без сомнения, точка зрения Ю. Хабермаса кажется в немалой степени идеалистической, но в ней, безусловно, сформулирован образец общественных отношений, при котором становится возможным мир и стабильность, становление делиберативной демократии. Еще 50 лет назад невозможно было представить такое широкое участие акторов всех сфер общественных отношений в общественной и государственной жизни, в том числе при принятии властных решений. Коммуникативный дискурс все больше и больше проникает в нашу жизнь. Повседневная практика жизни - это сообщество людей, говорящих друг с другом и открытых для сотрудничества.

Мораль для Ю. Хабермаса, как уже говорилось, - это те нормы, которые признаются справедливыми для конкретных сообществ. Лица, проживающие в таких сообществах, находятся внутри ситуации коммуникации, а потому существуют нормы, необходимые для регулирования интеракций ${ }^{68}$. Конфоликты могут быть разрешены на основе равной общей заинтересованности каждой из сторон, и такой способ разрешения конфликтов - более высокая ступень общественной жизни, чем достижение компромисса. Вместе с тем Ю. Хабермас все же допускает ситуации, когда сталкиваются разные этосы, выявляются глубинные конфликты, где правящий режим (нацизм в Германии, фашизм в Италии) выступает против своего народа. В соответствии с историческим опытом и коллективным самосознанием нация принимает решение о наказании и покаянии. Правда, иногда предпринимаются попытки оправдания режимов. Разные культуры, где сформировались разные нравы решают эти вопросы по-своему. Эти морально-эмпирические фракты подтверждают отсут-

${ }^{65}$ См.: Хабермас Ю. Вовлечение Другого. Очерки политической теории. С. 101.

${ }^{66}$ См.: Там же. С. 107.

67 Чтобы лучше понять мысли Ю. Хабермаса в этой области автор рекомендует обратиться к работе мыслителя «Будущее человеческой природы. На пути к либеральной евгенике» (М., 2002).

${ }^{68}$ См.: Хаберлас Ю. Будущее человеческой природы. На пути к либеральной евгенике. М., 2002. С. 51. 
ствие метафизических оснований морали, когда каждый культурный социум решает вопрос по-своему. Но это касается не только культуры, но также представляет собой вопрос интуиции. Разные коммуникативные сообщества представляют свои системы объяснения, связанные со многими вопросами, например о месте человека в космической реальности. То есть существующий моральный “код» имеет антропологический контекст обоснования. Если в плюралистических обществах метафизические и религиозные системы могут быть обоснованием нравственности и справедливости, то в условиях постметафизического мышления самосознание и самопонимание отрицают существование универсальных норм и моделей, а соответственно, их претензии на общезначимость. Вместе с тем неверным является утверждение, что разумная мораль, которая стала обоснованием прав человека, является просто историческим этапом развития культуры и, соответственно, права. Ю. Хабермас - отнюдь не воинствующий атеист; на его взгляды глубокое влияние оказала личность Й. Ратцингера (римского папы Бенедикта XVI). Отрицая универсальность морали, Ю. Хабермас называет религиозные и метафизические системы великими «мировыми контекстами в которых укоренена вся структура нашего морального опыта» ${ }^{69}$. Развитые религиозные системы, обладающие философской доктриной, безусловно, являются базой для формирования моральных сообществ. Бессмысленно отрицать, что западная мораль - это мораль христианская. Даже борьба с ней и отрицание доказывают ее глубокое укоренение в европейском и во всем западном обществе. В своей книге «Между натурализмом и религией. Философокие статьи» Ю. Хабермас говорит о возобновлении дискуссии о свободе и детерминизме. Он пишет: «Путь к критическому разъяснению границ многомерного, не только на отношении к объективному миру фриксированного разума ... представляет собой реконструкцию истории собственного возникновения» ${ }^{70}$. Такие понятия, как индивидуальность, автономия, эмансипация, солидарность, - это наследие метафизики, и постметафизическое мышление не может отвергнуть его. Более того, на этих понятиях постметафизика и пытается выстроить свои теории и, следовательно, черпает свои основания в метафизике и религии. Но все же Ю. Хабермас отводит метафизике роль исторического этапа в развитии науки и человеческой коммуникации. Общественная мораль не основывается на чем-то трансцендентальном: «философский дискурс о морали (и праве. - Ю. С.) ограничен социокультурным жизненным миром» ${ }^{71}$. Каждое общество рождает свои нормативы. Интересно также, что Ю. Хабермас не связывает дискурс о морали с категориями добра и зла, что роднит его с утилитаристами.

Оппонентом Ю. Хабермаса выступил К. О. Апель, также представитель концепции коммуникативного действия. Он не отказался от поиска

${ }^{69}$ Там же. С. 53

${ }^{70}$ Хаберлас Ю. Между натурализмом и религией. Философские статьи. М., 2011. C. 35.

71 Там же. 


\section{Вестник ВГУ. Серия: Право}

трансцендентных оснований морали, в то время как Хабермас указал, что универсальность дискурса может быть эксплицирована только из контекста истории. К. О. Апель принимает именно универсальный трансцендентализм в оценке морали. А. В. Назарчук пишет, что К. О. Апель в сознательном возрасте пережил эпоху национал-социализма и видел, какие трансформации претерпевают моральные ориентиры. Возможно, поэтому он не поддержал идею нейтральности дискурса, поскольку задача нравственности - «выявлять и подавлять опасное и поддерживать благопристойное» ${ }^{72}$. Таким образом, дискурс эксплицируется не из конкретного исторического контекста, а из сферы аподиктически Должного.

На первый взгляд, позиция Ю. Хабермаса вполне обоснована и подтверждается разнообразностью культур, общественных ценностей, характером общественных коммуникаций. Но если посмотреть глубже, оказывается, что во всех обществах и во все времена в разнообразных источниках звучат идеи свободы, равенства, уважения к человеку, необходимость защиты его достоинства, стремление обладать собственностью. Какими бы дорогами человечество ни ходило, оно неизбежно приходит к признанию естественного закона как некой константы, которая не дает обществу впасть в хаос. Конечно, не признавать плюрализм различных общественных систем, в том числе особенностей социальной норматики, означает отрицание очевидного. Но также неправильным было бы признание абсолютного разнообразия, использование в качестве отправной точки именно несхожесть. Крайне неосмотрительно признавать также правом все те нормы, которые исходят от власти. Здесь уместно привести цитату из «Братьев Карамазовых», когда являющийся к Ивану Карамазову черт говорит о способах разрушения общества и нравственности: «По-моему, и разрушать ничего не надо, а надо только разрушить в человечестве идею Бога, все с чего надо приняться за дело. С этого, с этого надо начинать, о слепцы ничего не понимающие! Там, где стану я (то есть чёрт. - Ю. С.), там сейчас же будет первое место ... все дозволено и шабаш» ${ }^{73}$.

В защиту естественного права следует отметить, что, несмотря на попытки отказаться от него, предать его забвению, идея его неустранима из сознания людей, она постоянно возрождается.

$96{ }^{72}$ Назарчук А. В. Ю. Хабермас и К. О. Апель : два подхода к обоснованию теории общества в современной немецкой философии. URL: http://sbiblio.com/biblio/ archive/nasarchuk_ju

${ }^{73}$ Достоевский Ф. М. Братья Карамазовы // ЛитМир - Электронная библиотека. С. 171.

Воронежский государственный университет

Сорокина Ю. В., профбессор кафеедрь теории и истории государства и права

E-mail: yulia_sor@mail.ru
Voronezh State University

Sorokina Yu. V., Professor of the Theory and History of State and Law Department

E-mail:yulia_sor@mail.ru 